\title{
A Retrospect on the Attitudes to the City of the Early Americans
}

\author{
Changyun Yang
}

Department of History, Jiangxi Normal University, Nanchang, 330022, China

\section{Keywords: American Cities. Intellectuals. Fear of the City. Adjust to the City. Anti-Urbanism}

\begin{abstract}
In American early history, the great men such as Thomas Jefferson had attitudes of "fear of the city", that is the bias of "anti-city". Since 1860s which was a period of "Rapid Urbanization", the attitudes of "fear of the city" began to increasingly transfer. In the late of the 19th century, American intellectuals such as John Dewey acknowledged that the urbanization was an "inescapable” process; the attitudes to the city of the Americans gradually became a kind of spiritual motive which would promote the progressive urban reform. They revealed variant urban problems fearlessly, but their purposes were to awake the public consciousness, to educate them to "adjust" to the city, and then to reform the cities, to refresh the city politics, and to clean up the shame of the cities. This article chooses the typical American writers or intellectuals over one century in American history, to clear up their attitudes to the city, thus to explore the inherence and characters of the evolution of the attitudes to the city of the early Americans.
\end{abstract}

\section{Foreword}

Although the city has played a significant role in the war of independence of North American colonies, the Americans' attitudes on city had experienced a historical process which included how to understand the city and how to adjust to life in the city. In this process, anti-urbanism, anti-city bias, or anti-urban sentiment can be used to summarize the attitudes to the city of the early Americans. [1]Until today, the attitudes of "anti-city" also exist on the mind of some of the Americans. Some scholars have indicated, "anti-city" is the representation of the "fear of the city", but I find that, the attitudes to the city of the Americans have a long evolution from the "fear" to the "adjust", eventually some of them even abandoned the "anti-city bias" and instead to advocate urban reform positively.This article will discuss the evolution of the attitudes to the city of the early Americans in the context of "Rapid Urbanization” since 1860s.

\section{"Fear of the City"}

As early as 1787, Thomas Jefferson manifested his hate to big cities, "While we have land to labor then, let us never wish to see our citizens occupied at a workbench, or twirling a distaff. Carpenters, masons, smiths, are wanting in husbandry; but, for the general operations of manufacture, let our workshops remain in Europe. It is better to carry provisions and materials to workmen there, than bring them to the provisions and materials, and with them their manners and principles. The loss by the transportation of commodities across the Atlantic will be made up in happiness and permanence of government. The mobs of great cities add just so much to the support of pure government, as sores do to the strength of the human body." [2]Jefferson's fear of "mobs of great cities” may be just as Socrates' sagacity of "Evils" in city-states.

Early American intellectuals such as Emerson and Hawthorne witnessed the development of urbanization produced by industrialization in the early the $19^{\text {th }}$ century and the changes of American landscape. As a generation who cherished natural and rural America, these (i.e. the changes of cities' appearance, or the growth of urban populations) being out of individuals and different from frontier which had a nature of wildness induced them turn to their attention toward "transcendentalism" in 1830 s and 1840s. Emerson wrote that "one man is a counterpoise to a city, ----that a man is stronger than a city, that his solitude is more prevalent and beneficent than the concert of crowds." [3]He suspected the capacity of the city radically, as he ever thought that "Cities give not the human senses room enough.” [4]In a lecture, Emerson announced the ignorance of the inhabitants of cities, he said, 
"the inhabitants of cities suppose that the country landscape is pleasant only half the year." [5]And in another part, he added to, "These facts may suggest the advantage which the country-life possesses, for a powerful mind, over the artificial and curtailed life of cities.” [5]In the mid-19-century, Emerson's attitude to the city was typical, like Emerson, Hawthorne and Thoreau, he also abhorred the bustling crowds in the cities. They all thought of their independence as an individual, and persevered in a lonely life. Hawthorne inhabited in Brook Farm for a while writing his wry novel The Blithedale Romance; while Thoreau escaped from city to Walden Pond, watching the nature by his heart, leaving behind an excellent essay Walden which the Whites called it as "a bible of anti-urbanism". [6] In a letter to Emerson, Thoreau said, "I don't like the city better, the more I see it, but worse. I am ashamed of my eyes that behold it. It is a thousand times meaner than I could have imagined. It will be something to hate, -that's the advantage it will be to me; and even the best people in it are a part of it, and talk coolly about it. The pigs in the street are the most respectable part of the population. When will the world learn that a million men are of no importance compared with one man?” [7] These words indicate a transcendentalist's fear of the city. Speak of Thoreau, Allan Poe "could have replied that Thoreau had nothing to look at but his reflection in Walden Pond." [8] And Allan Poe would have agreed with his European disciple Charles Pierre Baudelaire on the cultural sacredness of the great cities. Poe chose violence and scandal of New York in the 1840s as his writing materials, as an originator of Whodunit, who born in Boston and fated to die in Baltimore, he thought the city was not paradise. His destine drunk to die was exactly a true portraiture and a typical character of "low" urban life.[8]

If say the fear of the city of the Americans during 1830s and 1840s were more or less related with the Panic of 1837, which induced them generally to abhor Eastern commercial cities such as New York. Just like his grandfather John Quincy Adams and his great-grandfather John Adams, Henry Adams extremely hated Boston where he was born and thought of the financial district on State Street as their antithesis.[8] He added to, "Men died like flies under the strain and Boston grew suddenly old, haggard and thin." [9]

Henry James has started his writing of American Scene since 1870; he has depicted American customs of natives poetically, and also revealed the problems of the American great cities. In the chapter of "New York Revisited", he said, "Your condition was not reduced to the endless vista of a clogged tube, of a thoroughfare occupied as to the narrow central ridge with trolley-cars stuffed to suffocation, and as to the mere margin, on either side, with snow-banks resulting from the cleared rails and offering themselves as a field for all remaining action......the New York predicament leaves far behind the anguish represented in the Vatican figures." [10] His reveal to the conditions of the slums (Ghettos) was more profoundly ruthlessly, he said, "The children swarmed above all here was multiplication with a vengeance; and the number of very old persons, of either sex, was almost equally remarkable; the very old persons being in equal vague occupation of the doorstep, pavement, curbstone, gutter, roadway, and every one alike using the street for overflow. As over flow, in the whole quarter, is the main fact of life I was to learn later on that, with the exception of some shy corner of Asia, no district in the world known to the statistician has so many inhabitants to the yard the scene hummed with the human presence beyond any I had ever faced in quest even of refreshment; producing part of the impression, moreover, no doubt, as a direct consequence of the intensity of the Jewish aspect." [10]Maybe his descriptions of the cities had brought antipathy to the city among his fans and even himself.

Edith Wharton, who was the author of The Age of Innocence, also disliked American cities in the late of the $19^{\text {th }}$ century. The same to Henry James and Henry Adams, she thought of that, "the trouble with the city, is democracy, the influx of ignorant masses, their lack of manners, their lack of standards."[8] As American intellectuals in the second half of the $19^{\text {th }}$ century, they were elites and were born in rich families. Because they were from the upper ten, they spontaneously blamed the trouble with the city on low masses, thus had an inclination to "fear of the city". American romantic literary writers such as Herman Melville and provincial writers such as Willa Cather would have not been as lucky as them however, they had not been born in rich families. In Melville's childhood, his father was a case of crabs as a businessman, then the conditions of the all the families were suddenly 
bad. As his birth place, New York didn't give chances and wealth to him, moreover, he was frustrated in writing during he inhabited there. So Melville hated New York badly as a symbol of his merchant father's bankruptcy and of his own worldly failure as an author.[8] In July, 1863, Melville wrote a poem of The House-Top: A Night Piece. In Melville's opinion, the city is an artificial product, and the human only if came back to Nature, then would have saved themselves. And this may be the tune of his novel Moby Dick, which man's power would have been showed in the intercourse between human and Nature. So did Willa Cather, although she spent her afterlife in New York, but her materials of writing were mostly from Nebraska where she was born, she had pictured herself as Alexandera Bergson in her novel $O$ Pioneers!, which indicated her love for countryside.

\section{“Adjust to the city"}

As the Whites have indicated, "the fact is that at the end of the nineteenth century there emerged a tendency to view the American city in a more friendly manner."[6] William James who was the pioneer of American pragmatism had a different attitude to the city from his little brother Henry James. Someone maybe ask why Henry James had an eclectic attitude to the city? My question is that he would have find urbanization is inescapable especially at the stage of "rapid urbanization", so he gave impersonal looks to the cities he had ever traveled, which implied some of changes of the attitudes to the city. If this was the fact, William James had not this change, because he had always shown a positive attitude to the city or urbanization, he had never thought of escaping from the city to the countryside. As for this, it was consistent with his "Hope", "Optimism" and "Possibility" shown in his philosophy. These characters allowed him to "view the urbanization of America in a way that might encourage Americans to do something about urban problems."[6] Maybe this view was the general attitude of the peoples in the age of progressive movement. I think of a writer once said, "the average worker for municipal improvement is disposed to take a hopeful view of the situation, and that conditions really are improving." [11] In the letter William James to Henry James in 1907, he said, "The first impression of New York, if you stay there not more than 36 hours, which has been my limit for twenty years past, is one of repulsion at the clangor, disorder, and permanent earthquake conditions. But this time, installed as I was at the Harvard Club (44th St.) in the centre of the cyclone, I caught the pulse of the machine, took up the rhythm, and vibrated mit, and found it simply magnificent......It is an entirely new New York, in soul as well as in body, from the old one, which looks like a village in retrospect." [12] He even commented Henry James's book The American Scene "is just out”, and added to, I'm surprised at you, Henry, not having been more enthusiastic, but perhaps that superbly powerful and beautiful subway was not opened when you were there. [12] In his opinion, modern industrialism could resolve the problems which produced by urbanization, so there were no any necessary to fear of the city. Like Whitman, William James found the virtue and promise in the American city, both of them not only accept the city as an inescapable part of America, but they enjoy it, as Jefferson most certainly did not. [6]

The Whites reviewed that a livable city on earth, one is tempted to say, is the social counterpart of James's pragmatism, and therefore he is one of the first great American writers to associate himself with the effort to accept what is good and to root out what is bad in the American city.[6] We must notice that, when William James found what is good in New York City, the Americans were in so-called progressive era in history. During this period, ordinary peoples generally accepted the idea of Progress, and believed in themselves the power of reform. Consequently the attitudes to the city of American great writers have transformed from pure "fear" to somewhat "hope" since the late of the $19^{\text {th }}$ century, and they strove to find some measures to solve the urban problems. The typical figures of this age such as Frederic C. Howe, Lincoln Steffens, Ida Tarbell, Jacob Riis, Jane Adams, Frederic L. Olmsted and John Dewey had a vivid difference from the older generations. But what will be mentioned is James Bryce who was an England observer and a critic on American issues was an important writer since 1880s, he had many reviews on the American city, his famous conclusion is "There is no denying that the government of cities is the one conspicuous failure of the United States. The deficiencies of the National government tell but little for evil on the welfare of the people. The 
faults of the State governments are insignificant compared with the extravagance, corruption, and mismanagement which mark the administrations of most of the great cities. For these evils are not confined to one or two cities." [13] In my opinion, I think, what Tocqueville inherited was the Aristotelian fear of the "city mobs" and then affected American Intellectuals to come into fear of the city. By contrary, James Bryce would have not antagonized the city, but to expose the problems in municipal governments and politics, which was in order to awake the civic consciousness and to seek the measure to resolve the problems. In 1890, the famous educator Andrew D. White said that, "without the slightest exaggeration we may assert that, with very few exceptions, the city governments of the United States are the worst in Christendom-the most expensive, the most inefficient, and the most corrupt." [14] White might not be fear of or abhor the city, he just revealed the difference between American cities and European cities, he thought of that the European cities are corporations and not political bodies; he suggested the questions in a city are not political questions, they have reference to the laying out of streets; to the erection of buildings; to the control of franchises and the like; and to provisions for the public health and comfort in parks, boulevards, libraries, and museums. [14] Unlike the intellectuals I have mentioned above such as William James and others, though White revealed the bad of the city, but he suggested some of measures to clear up these bad.

In the early of the $20^{\text {th }}$ century, political professor Charles Edward Merriam of Chicago University indicated that "the urban community specialized both in evil and in virtue: or more accurately, the modem industrial and social tendencies developed most rapidly in urban centers, and their strength and weakness was there most sharply accentuated; the lights and shadows of modem life were there most clearly painted." [15] As for the keyword of "Hope", we should not to overlook Frederic C. Howe. In the early of the $20^{\text {th }}$ century, many of the Americans depressed by the problems of the cities and immersed themselves to find some ways to resolve those problems, but more or less were frustrated. Howe picked up the stereotype of "the city and the democracy" and wrote the book The City: The Hope of Democracy in which he suggested with full confidence the direction and the outlet of the city. His attitude to the city is clearly, he stated, "the modern city marks an epoch in our civilization and the city is the head, heart, and centre of the nervous system.” [16] In another book The British City: The Beginnings of Democracy, Howe believed that "Democracy is having its beginnings in the city. The issue with which we are familiar in Chicago, Cleveland, Detroit, Cincinnati and elsewhere is the same issue that is uppermost in the cities of London, Glasgow, Manchester, Liverpool and Sheffield.” [17] What Howe had indicated was that all of the problems in the city would be resolved by the reforms which economic motive animated, just as the England cities had experienced. Moreover, about his thought of "the hope of the city", Howe was not just generalizing, he gave some measures, for example, he said, "the great cities of Australia are spread out into the suburbs in a splendid way. For miles about are broad roads, with small houses, gardens, and an opportunity for touch with the freer, sweeter life which the country offers.” [18]

In the progressive era, city-loving urban reformers like Howe, Adams and Tom L. Johnson, Hazen S. Pingree, Robert M. La Follette did exist among the American intellectuals and ordinary citizens. [6] Other intellectuals advocated improving the life of city by education, which was to training the people to adjust the life of in city. Andrew D. White I mentioned above once said, "the main argument for the existence of our public schools is that they are an absolute necessity to the existence of our Republic; that without preliminary education a Republic simply becomes an illiterate mob, that if illiterate elements control, the destruction of the Republic is sure." [14] A more famous person is John Dewey. As early as 1899, Dewey stated in a lecture, "population is hurriedly gathered into cities from the ends of the earth...... The obvious fact is that our social life has undergone a thorough and radical change. If our education is to have any meaning for life, it must pass through an equally complete transformation. This transformation is not something to appear suddenly, to be executed in a day by conscious purpose." [19] What Dewey obviously acknowledged is the transformation of the American society in the late of the $19^{\text {th }}$ century, and this "society" was "a society is a number of people held together because they are working along common lines, in a common spirit, and with reference to common aims." [19] From the statistics, the main change of American society of the late 
of the $19^{\text {th }}$ century was the transformation from rural society to urban society at large, or as the historian Richard Hofstadter's famous thesis, "the United States was born in the country and has moved to the city." [20] The transformation of the society inevitably induced the correspond change of the nature and the system of education. Dewey's attitude to the city of and its problems was not fear but optimism; he suggested that "At present, concentration of industry and division of labor have practically eliminated household and neighborhood occupations-at least for educational purposes. But it is useless to bemoan the departure of the good old days of children's modesty, reverence, and implicit obedience, if we expect merely by bemoaning and by exhortation to bring them back. It is radical conditions which have changed, and only an equally radical change in education suffices. We must recognize our compensations - the increase in toleration, in breadth of social judgment, the larger acquaintance with human nature, the sharpened alertness in reading signs of character and interpreting social situations, greater accuracy of adaptation to differing personalities, contact with greater commercial activities. These considerations mean much to the city-bred child of today.” [19] In Dewey's opinion, life in the city has become the most manifest feature of the modern world, and any theory of education should not ignore the fact of urbanization, so the problem of education was how to adjust the child to life in the city. [21]

\section{Conclusion}

From the perspective of "length theory", the evolution of the attitudes to the city of the early Americans was conspicuous. The fear of the city as an attitude still exists today which may be an explanation to the phenomena of suburbanization. Nevertheless, attitudes of the early Americans that would certainly influence the consciousness of the public indeed had a conspicuous evolution. What I said in this article is not the all of the truth, but a clue to understand the attitudes to the city of the early Americans which showed in their writings. Even so, we can acknowledge more about the history or to say more truth of the turn of the $20^{\text {th }}$ century and to verify how the ideas of "good government", "the better city" and "the hope of the city" were born. [22] Thus, we can find that the public attitudes to the city have also transformed from the "fear" to the "adjust". These days, more and more people may question the German saying "StadtLuft macht frei" (urban air makes you free), but in the context of modernization, the idea which urban civilization is the criterion of the progress of the society is recognized by the majority.

\section{Acknowledgments}

This article is one of research productions of “A Study on Citizen's Participation in American Urban Reform in the Early Twentieth Century”, which is as a Youth Program funded by Ministry of Education, program number is 11YJC770075; and also funded by Jiangxi Normal University in the "Young Talent Funding Program".

\section{References}

[1] Leo Srole, “Urbanization and Mental Health: Some Reformulation”, American Scientist, Vol. 60, No. 5 (September-October 1972), p.576.

[2] Thomas Jefferson, “Manufactures” (1787), in Sharon M. Meagher, ed., Philosophy and the City: Classic to Contemporary Writings, State University of New York Press, 2008, pp. 81-82.

[3] Ralph Waldo Emerson, “Journal”, in Journals of Ralph Waldo Emerson, Vol. 5, Edward Waldo Emerson and Waldo Emerson Forbes, ed., London: Constable \& Co., Limited, Boston and New York: Houghton Mifflin Company, 1911, p. 474.

[4] Ralph Waldo Emerson, “Nature, Essays by Ralph Waldo Emerson, The Complete Works of Ralph Waldo Emerson, Volume III, Boston and New York: Houghton Mifflin Company, 1903, p. 171. 
[5] Ralph Waldo Emerson, "Nature” , The Complete Works of Ralph Waldo Emerson, Volume I , Boston and New York: Houghton Mifflin Company, 1903, p. 18.

[6] Morton Gabriel White, Lucia White, The Intellectual versus the City, from Thomas Jefferson to Frank Lloyd Wright, Cambridge, Mass: Harvard University Press, 1962, p. 168.

[7] F. B. Sanborn, “The Emerson-Thoreau Correspondence: The Dial Period”, The Atlantic Monthly, May 1892, p. 588.

[8] Alfred Kazin, Fear of the City 1783 to 1983, American Heritage, Volume 34, Issue 2, March 1983, p.3.

[9] Henry Adams, The Education of Henry Adams, Washington: Harvard University Press, 1907, p. 295.

[10] Henry James, The American Scene, London: George Bell \& Sons and Bombay, 1907, pp. 88-89.

[11] Clinton Rogers Woodruff, “Municipal Progress, 1904-1905”, Annals of the American Academy of Political and Social Science, Vol.27, (Jan. 1906), p. 196.

[12] Henry James, The Letters of William James, Volume II, Boston: The Atlantic Monthly Press, 1920, p. 264.

[13] James Bryce, The American Commonwealth, Vol. 1, London; New York: Macmillan, 1895, p. 637.

[14] Andrew D. White, “City Affairs are not Political”, see also The Government of American Cities (Forum, December, 1890, pp.213-216). A web edition see http://www2.fiu.edu/ revellk/pad3003/White.pdf.

[15] Charles Edward Merriam, American Political Ideas: Studies in the Development of American Political Thought, 1865-1917, New York: The Macmillan Company, 1920, p. 247.

[16] Frederic C. Howe, The City: The Hope of Democracy, New York: Charles Scribner's Sons, 1905, p. 9, p. 22.

[17] Frederic C. Howe, The British City: The Beginnings of Democracy, New York: Charles Scribner's Sons, 1907, pp. xii-xiii.

[18] Frederic C. Howe, The City: The Hope of Democracy, p. 204. As for this, the Whites reviewed, "he is, it would appear, a suburban booster rather than a city-lover." See Morton White and Lucia White, "The American Intellectual versus the American City”, p. 174.

[19] John Dewey, The School and Society, Chicago: the University of Chicago Press, 1899, p. 18, p. 39.

[20] Richard Hofstadter, The Age of Reform: from Bryan to F.D.R, New York: Knopf, 1955, p. 23.

[21] See also, “The American Intellectual versus the American City”, p. 175.

[22] For "good government", see Thomas Jefferson, "To the Republican Citizens of Washington County, Maryland, Assembled at Hagerstown on the 6th Instant, Moticello, March 31, 1809”, The Writing of Thomas Jefferson, H. A., ed., Washington, D.C., 1871, p.165.); for "better city”, see Dana Webster Bartlett, The Better City: a Sociological Study of a Modern City, Los Angeles: The Neuner Co. Press, 1907; for "hope”, see Frederic C. Howe, The City: The Hope of Democracy; or "promise”, see Morton White and Lucia White, "The American Intellectual versus the American City”, p. 173. 